\title{
Global Agro-food Governance, Supermarket Chain Expansionism and Household Food Insecurity in Rural South Africa
}

\author{
Professor Johannes Tsheola \\ Department of Development Planning \& Management, University of Limpopo, South Africa \\ johannes.tsheola@ul.ac.za
}

\section{Doi:10.5901/mjss.2014.v5n8p656}

\section{Abstract}

\begin{abstract}
Global governance of agricultural markets has enforced the collapse of conventional rural agricultural production systems and eroded tenuous guarantees of household food security. With the ascendency of global agro-food governance, transitory food insecurity increasingly evolved into moderate chronic vulnerability among rural households in most developing economies. The exposure of household and smallholder food self-provisioning systems to stressors attendant to global agro-food governance through, among other factors, commodity and food pricing, production, marketing, distribution and expansion of supermarket food chains, undermined rural household food security. As conventional mainstay for food security in rural South Africa, the collapse of household and smallholder food self-provisioning triggered disproportionate exposure to risks and increased vulnerability to both chronic and transitory food insecurity. This article concedes that global agro-food governance, through food agents and supermarket expansionism, have conditioned rural households into deficit producers and net consumers of purchased foods. It contents that the moderate chronic household food insecurity within rural South Africa, wherein the majority merely avoid hunger, is intricately connected to the liberalized and deregulated global agro-food governance.
\end{abstract}

Keywords: Global Agro-food Governance; Agricultural Markets; Supermarket Food Chains; Food (In)security; Rural South Africa

\section{Introduction}

With the ascendency of neoliberal globalization, the "articulation between farming and corporate sectors of the agro-food system" became increasingly complex and contested (Whatmore, 1995, p.45). Simultaneously, bio-fuel production introduced new drivers of global food prices involving the reallocation of resources and outputs to the supply of feedstock, speculation in commodity markets and the power of agents within the agro-food chain, namely supermarkets, processors and distributors (Campbell and Le Heron, 2007; von Braun, 2007; Altman, Hart and Jacobs, 2009; Moore, 2010; Murphy, 2010; Schurman and Munro, 2010; van der Ploeg, 2010; Buyx and Tait, 2011; Marsden, 2011; van der Horst \& Vermeylen, 2011). For these reasons, availability of food, whereas significant, no longer conclusively determine food security status; instead, household purchasing power, which is dependent upon market integration, pricing and marketing, has become a fundamental determinant of food access, itself intricately embedded with complex configuration of society, both historically, culturally, socially, economically, politically and geographically (Webb et al., 2006; Devereux, 2009; Drimie and Casale, 2009; Hart, 2009; Ghosh, 2010). However, the hegemonic discourse that capitalist neoliberalism of "trading connections freed of restrictions, with a domestic environment made internationally competitive through deregulation, privatization, wage restraint, and prudence in government spending" is the most efficient system (Peet, 2002, p.79), has persisted. Hence, electricity supplies, domestically, and the rising oil prices, internationally, collude to create upward pressure on food prices because of the inter-linkages with petroleum, which is an input for chemical fertilizers and agro-food transport costs (Renard, 2003; Altman et al., 2009; Bridge, 2010; Ghosh, 2010).

Simultaneously, the post-war political-economy of agriculture transcended the farm gate to embrace two interrelated dimensions of capital accumulation and social regulation, with the result that the production, marketing, pricing and distribution of food became intimately globally interconnected and intertwined in highly industrialized and intensively globalized networks of institutions, technologies and products, collectively denoted "agro-food system" (Whatmore, 1995; Busch and Bain, 2004; Friedmann, 2005; Anderson, 2006; Weiss, 2007; Burch and Lawrence, 2009; Godfrey et al., 2010; Moore, 2010; van der Ploeg, 2010; Holt-Gimenez and Shattuck, 2011; Horlings and Marsden, 2011; Marsden, 2011). The latter is symbolized by the "global presence and cross-cultural potency" of food icons such as Kentucky Fried Chicken, McDonalds, Pizza Hut and Burger King (Friedberg, 2004; Lang and Heasman, 2004; Fonte, 2006; Fulponi, 2006; Maloni and Brown, 2006; Campbell and Le Heron, 2007; Lang, 2010; Parfitt, Barthel and MacNaughton, 2010). These global food icons involve "the set of activities and relationships that interact to determine 
what, how much, by what method and for whom food is produced and distributed" (Organization for Economic Cooperation and Development, 1981 in Whatmore, 1995, p.37). Their imposition of global governance for food production, marketing, pricing, distribution and consumption eroded conventional rural household and smallholder food self-provisioning, which has historically served as the mainstay of food security in developing economies (DuPluis and Goodman, 2005; Halfacree, 2007). Governance of these global agro-food systems incorporates synthesized interests of global institutions and local business federations whilst turning "a compassionate face on social problems moralized as poverty, illness, and ignorance" (Peet, 2002, p.79). Consequently, global agro-food governance has dramatically altered food production, marketing, pricing, distribution and consumption, even for the remotest rural localities in developing economies (McMichael, 2004; Oldewage-Theron, Dicks and Napier, 2006; Weiss, 2007; Schurman and Munro, 2010; van der Ploeg, 2010; Rosin, 2012; Sage, 2012; Stock and Carolan, 2012).

One of the manifestations of the global agro-food governance in rural South Africa involves the expansion of supermarket food chains into local food markets. Altman et al. (2009) observe that with the increased connectivity between the local, national and international commodity chains and economic networks, even remote rural households in South Africa are affected. Generally, the panoply of policy prescriptions produced has been detrimental to rural economies because of the "cultural-institutional-geographical" contexts of their production (Peet, 2002; Traub and Jayne, 2008; Aliber, 2009; Baiphethi and Jacobs, 2009; Hart, 2009; Jacobs, 2008, 2009a, 2009b). A sensible deduction should assert that food crisis, hunger and malnutrition would persist for developing economies, unless if the agro-food system is drastically restructured (Lang and Heasman, 2004; McMichael, 2004; Evans, 2009; Lang, 2010; Moore, 2010; van der Ploeg, 2010; Holt-Gemenez and Shattuck, 2011). The embeddedness of rural South Africa's food insecurity with the globalized agro-food governance entails theorization of their relationships through the supermarket food chain expansionism. This article demonstrates that the collapse of the conventional mainstay for food security in rural South Africa, household and smallholder food self-provisioning, precipitated by global agro-food governance and driven through food agents and supermarket expansionism, triggered disproportionate exposure to risks and increased vulnerability to both chronic and transitory food insecurity. It contents that the moderate chronic household food insecurity within rural South Africa, wherein avoidance of hunger, rather than attainment of balanced diets, is primate, is intricately connected to the liberalized and deregulated global agro-food governance.

\section{Global Agro-food Governance: Supermarket Chains, Rurality and Household Food Insecurity}

The post-war restructuring of the agricultural production involved deep insertion into the global networks of agrotechnology and food industries through the "ties of technological dependence, debt and production contracts", as well as highly skewed differentiation of food consumption (Whatmore, 1995, p.46). As the invisible hand of the market successfully solicited supplementation from the visible hand of the state in general (Glemarec and Puppim de Oliveira, 2012), the private sector search for profit and the state's concerns with "securing social order" interfaced in the global agro-food governance nexus (Essex, 2011). The ascendency of agro-food markets has meant that virtually all stable foods are priced according to the liberalized global pricing regime wherein "the instabilities of global prices" are transmitted directly into "domestic price fluctuations", with the result that smallholder producers and informal traders are squeezed out of business (Jacobs, 2008, p.6). Developing economies' food security came to be intricately connected to issues of social protection, sources of income, rural-urban development dichotomy, household economy of affection, as well as access to land and water resources, retail markets, education and nutritional information (Friedmann, 2005; Fonte, 2006; Campbell and Le Heron, 2007; Altman et al., 2009; Burch and Lawrence, 2009; Ghosh, 2010; Holt-Gimenez and Shattuck, 2011; Marsden, 2011).

The most adversarial, dramatic and long-lasting impact of the prominence of the global agro-food industrial governance has been the reorientation of the entire food production capacity of developing countries away from staple foods to crops for exportation (Lang, 2010; Schurman and Munro, 2010; van der Ploeg, 2010; Makhura, 2013). Generally, agricultural production in developing economies is, in accordance with the trade structure, vertically tied into Western markets for unseasonal, luxury primary goods and bulk feed crops for intensive livestock production (Land and Heasman, 2004; D'Haese and van Huylenbroeck, 2005; van der Ploeg, 2010; Stock and Carolan, 2012). Hence, there exist agribusiness international monopolies operated by the few global food icons, which affect manufacturing and distribution of farm supplies, farm production operations, storage, processing and distribution of commodities and by-products (Friedberg, 2004; Campbell and Le Heron, 2007; Schurman and Munro, 2010). Through agricultural commodity chains, food production has adopted the industrial character of similar businesses and industries, creating therefore agro-food complex of "industrial relations of the production and consumption of specific foodstuffs" and dietary standards of beef, canned, frozen and such other "durable food", in association with "distinct agro-food regimes" (Whatmore, 1995, p.39). 
The latter concept involves explorations of social regulation in agro-food systems, wherein regulatory apparatus are attempted to manage and sustain world agricultural markets and food prices, as well as social conditions of capital accumulation within states (Busch and Bain, 2004; McMichael, 2004; Friedmann, 2005; van der Ploeg, 2008, 2010; Burch and Lawrence, 2009; Holt-Gimenez and Shattuck, 2011; Marsden, 2011; Sage, 2012). In South Africa, like in many such other developing economies, the deregulated and liberalized regulatory agricultural environment has virtually handed the food security plight of the rural poor over to global free markets.

Food security for the majority of rural households in developing countries is now a function of purchasing power, the ability to earn off-farm cash income and the food prices, which are determined by marketing efficiency and distribution systems (Baiphethi and Jacobs, 2009). Inevitably, calorific and food intake among poor rural people dropped as global food prices escalated, precipitating experiences of hunger, malnutrition and food insecurity (DuPluis and Goodman, 2005; Halfacree, 2007; Ghosh, 2010; Essex, 2011). Global restructuring and industrialization of the agricultural sector was justified on the grounds that the biological foundations of agricultural production constrained capital accumulation because, being a land-based activity, agriculture was understood to be unattractive to direct involvement of industrial capital and business (Gebbers and Adamchuck, 2010; Moore, 2010; Horlings and Marsden, 2011; Marsden, 2011; Sage, 2012). To this extent, commercialization of agriculture involved technological modification of biological processes in farming as well as valorization of agricultural products off-farm in the manufacture of technological farm inputs and the increased processing and packaging of food products after they have left the farm gate (Moore, 2010; Schurman and Munro, 2010; van der Ploeg, 2010; Horlings and Marsden, 2011; Stock and Carolan, 2012). Corporatization of farming proceeded through the twin processes of appropriation and substitution, which circumvented and, simultaneously, undermined the rural poor's food self-provisioning systems in developing countries. Whereas appropriationism meant that elements that were once integral to the agricultural production process are extracted and transformed into industrial activities, and then ultimately reincorporated into agriculture as inputs, substitutionism reduces agricultural products to industrial inputs and replaces them by fabricated and/or synthetic non-agricultural components in food manufacturing (Moore, 2010; Murphy, 2010; Schurman and Munro, 2010; van der Ploeg, 2010; Buyx and Tait, 2011; van der Horst and Vermeylen, 2011).

Inevitably, the number of farms declined and the remaining few grew into much larger business entities bound to the corporate agro-food sector through a variety of economic and knowledge ties, simultaneously with the diversification of the wider struggles over rurally-based food self-provisioning (Halfacree, 2007). Hart (2009, p.362) affirms that "recent high food prices and changes in the world food situation are exacerbating the conditions of households that are vulnerable to food insecurity", especially those with weak livelihoods. The World Bank (2007) too concedes that the volatility of foreign exchange rates, the import parity pricing, lack of tradability of locally produced food stables and variability of domestic production have colluded to escalate both transitory and chronic food insecurity among the poor rural households. The fracturing of the household-based production in developing economies occurred simultaneously as the "social distance between producers and consumers at the heart of the system and those on its periphery" was magnified (Whatmore, 1995, p.48). Currently, "the ability to access food is strongly influenced by the broader context (local, national and global) and systems or networks (economic, social, political and environmental) in which South African households pursue their livelihoods" (Hart, 2009, p.366). Despite deeply valuing farming and food selfprovisioning, rural households are increasingly forced to seek for non-agricultural income sources due to the proliferation of cash needs (Jacobs, 2009b). Rural South Africa too is embedded with these longstanding, yet highly volatile, systems and networks of agro-food globalism, wherein household access to adequate food increasingly depends on the functioning of food markets and distribution systems rather than only on total agro-food output (Lang and Heasman, 2004; Altman et al., 2009; Essex, 2011; Makhura, 2013). South Africa has deregulated maize, wheat and fruits production, marketing and distribution; and, rural households experience the worst effects thereof (Jacobs, 2008; Makhura, 2013).

\section{Vulnerability to Food Insecurity: Temporal and Intensity Dimensions}

As a property of the systems and networks, rather than of individuals, vulnerability is a complex, context-specific phenomenon, whose causes cannot be generalized. It involves the degree of exposure to factors that threaten well-being as well as the extent to which individuals, households, social groups or nations respond, cope and overcome such elements (Hart, 2009). Given its external and internal dimensions, vulnerability involves "the interaction of multiple causal factors at different levels in the broader systems" within which household livelihoods are embedded, as well as consequences of "the functioning", or lack thereof, of the systems and networks of globalism, the ability to cope and the interconnectedness of the local and global dynamics (Hart, 2009, p.369). External vulnerability refers to "the structural 
elements that determine sensitivity and risk to exposure", caused and shaped by "the interactions of socio-economic, political and biophysical factors" (Hart, 2009, p.368), which include "economic globalization" wherein exposure is determined by the existence of systems and networks of globalism that either cause or reduce the likelihood of food insecurity (Drimie and Casale, 2009). Conversely, internal vulnerability encapsulates the ability of households to respond, cope, reduce and overcome the "stressors" and their undesirable effects (Drimie \& Casale, 2009). Unavoidably, understanding vulnerability to food insecurity entails "a synthesis of past and current circumstances" (Hart, 2009, p.374). It is therefore delusional to try to understand and resolve food insecurity of the majority of poor rural households in territories of the former Bantustans in South Africa without exploring the systems and networks of colonialism, separate development, apartheid spatial development and the on-going hegemonic neoliberalism.

The Food and Agricultural Organization (FAO) $(2001,2006)$ defines food security as the circumstances under which individuals, households, nations and the global community of people have, at all times, physical, social and economic access to sufficient, safe and nutritious foods that meet their dietary needs and preferences for healthy and active life (cited in Altman et al., 2009). The majority of rural households in developing countries have given up the fight against under-nutrition by placing greater emphasis on avoidance of hunger through intake of more grain products than energy-intensive foods (Oldewage-Theron et al., 2006; del Ninno, Dorosh and Subbarao, 2007; Aliber, 2009; Aliber and Hart, 2009; Altman et al., 2009; Baiphethi and Jacobs, 2009; Evans, 2009; Hart, 2009; Jacobs, 2009a, 2009b; Essex, 2011; Marsden, 2011). Such households are food insecure because their diets are not well-balanced or diversified. Within the globalized agro-food systems, households' purchasing power, dependent on markets, marketing and pricing, has become a key requirement to accessing nutritious food (Makhura, 2013) because it creates the possibility of meeting the dietary needs and preferences for healthy and active life (Webb et al., 2006; Devereux, 2009; Drimie and Casale, 2009). The concept of food insecurity has both the temporal and intensity dimensions. From the temporal dimension, food insecurity can be chronic, transitory, seasonal or recurrent transitory (Hart, 2009). The distinction between transitory and chronic food insecurity is vital to unpacking the factors that create vulnerability for the majority of poor rural households (Devereux, 2006; Jacobs, 2008; Altman et al., 2009; Hart, 2009). Chronic food insecurity refers to a state of both hunger and malnutrition which are long-term, persistent and almost continuous, whereas transitory food insecurity involves sudden onset of short-term or temporary status (Hart, 2009). When the latter is recurrent, happening almost every year prior to harvest and usually lasting for 2-3 months, it is often described as seasonal or cyclical or recurrent transitory food insecurity (Devereux, 2006; Jacobs, 2008; Hart 2009). The globalized agro-food systems and networks have converted the economically marginalized people, who lack productive and investment capital, into net buyers of food even during good farming seasons, whilst simultaneously enforcing the adoption of state policies that favor large-scale commercial producers over subsistent and smallholder production (Jacobs, 2009a). Poor rural households continue to control assets that are difficult to treat as investment and productive capital, implying that the globalized agro-food system within which rurality is embedded is itself central to the food insecurity of the poor rural households whose assets cannot be rented or sold as strategies for coping, reducing, adapting and overcoming the food security "stressors".

\section{Embeddedness of Rural South Africa with Global Agro-food Governance and Supermarket Food Chain Expansionism}

South Africa's domestic agri-industry has now been firmly locked with the global agro-food systems and networks. Since at least 1996, South Africa's agricultural marketing policies sought to liberalize and deregulate the full agricultural value chain in an approach described as "big-bang", which created agro-food sub-hegemonic regional systems in which the most food-insecure households experienced perpetual risks and threats as the cost of their staples escalate drastically (Jacobs, 2008, 2009a; Traub and Jayne, 2008). South Africa's agricultural market deregulation "coincided with macrolevel political economy reforms" initiated through the 1984 White Paper on Agriculture (Jacobs, 2008, p.8). The latter initiated far-reaching market-oriented reforms; and, the post-apartheid Marketing of Agricultural Products Act No 47 of 1996 provided for the integration of smallholder producers into the agricultural market (Jacobs, 2008, 2009a; Traub and Jayne, 2008). Basically, the Marketing of Agricultural Products Act of 1996 repealed the Marketing Act of 1968 by phasing-out the agricultural control boards and deregulating the agri-industry and sector (Makhura, 2013). Consequently, farmers were allowed to market and export own produce as well as import freely, introducing in the process chaos in the agri-industry wherein domestic interests came to compete against each other in international markets (Makhura, 2013). The chaos in the domestic agri-industry and sector, saw the Minister of Agriculture commissioning a 2006 Task Team, which recommended that "the bank (Land Bank) pursue a new business model that focused on developing subsistence farming and financing emerging farmers and, to a lesser extent, commercial farming" (Makhura, 2013, p.78).

In its endeavor to integrate smallholders into the agricultural market, the Marketing of Agricultural Products Act No 
47 of 1996 provided a liberalization and deregulation template within which all other policies, including the 1997 Land Reform Programme, the 2001 Strategic Plan for Agriculture and the 2006 Broad Based Black Economic Empowerment in Agriculture (Agri BBBEE), unfolded. Overall, the adoption of an international system of floating exchange rates in 1960s and "the deregulation of the agri-industry in the 1990s" were the two "most important structural changes that affected the agri-industry" (Makhura, 2013, p.95). Section 2 of the Act extends deregulation and liberalization to all other spheres of agriculture (Jacobs, 2008, 2009a). Together, Section 2(2) and 16 of this Marketing of Agricultural Products Act thrust smallholders into agro-food globalism and agricultural export chains (Jacobs, 2008, 2009a). Finally, this Marketing of Agricultural Products Act of 1996 fast-tracked the agricultural market reforms and repealed the separate legislative instruments, thrusting the poor smallholders from rural South Africa into harsh realities of neoliberal agro-food systems. By 2007, when "a memorandum was imposed on sequestrating emerging farmers experiencing financial distress", food prices were already escalating (Makhura, 2013, p.78) out of control. Demonstrably, under this Act, and the National Agricultural Marketing Council (NAMC) it established, market forces were unleashed as the drivers of business activity and resource allocation (Jacobs, 2008, 2009a). On its part, the 2001 Strategic Plan for Agriculture merely endorses this market-oriented approach and accepts that supermarket chains have become dominant in the agro-food value chains where they are powerful in negotiating and determining producer prices, locally and internationally (Jacobs, 2008, 2009a). As a result, "domestic producer prices are also influenced by the international prices of commodities and the exchange rate" (Makhura, 2013, p.94).

Thus, most rural households in South Africa that previously achieved food self-provisioning through subsistence production have increasingly purchased most of their foods, just like the urban populations, from the market, consisting of about $90 \%$ of their supplies in some cases (Baiphethi and Jacobs, 2009). Simultaneously, upward pressure has been exerted on food expenditure of poor rural households, reaching between $60 \%$ and $80 \%$ of total household income (Baiphethi and Jacobs, 2009; Aliber, 2009). Accordingly, Raj Patel argues that the South African government has "made poor choices in its agricultural policies" which expose poor rural households to higher food prices (cited in Tolsi, 2011, p.7). Given the "spatial fix" of apartheid Bantustans and the "unequal food economy", deregulation and liberalization of the food market (Makhura, 2013), especially maize, rendered South Africa's rural food security increasingly unsustainable. Given South Africa's historic "unequal food economy", production for self-provisioning has been the most realistic sustainable food security option for poor rural households (Aliber and Hart, 2009; Baiphethi and Jacobs, 2009). A recent Report by Oxfam, entitled "Growing a Better Future: Food Justice in a Resource-Constrained World" predicts that the increasing price of maize staple food would ultimately exacerbate demand for increased food budgets in sub-Saharan Africa where already calorific intake is the lowest in the world (cited in Tolsi, 2011, p.7).

Simultaneously, supermarkets expanded into remote locations where they intensified competition over local demand, forcing poor households and smallholders to become net consumers, rather than producers, of food (Jacobs, 2009a). Inevitably, rural South Africa came to experience a structural household food insecurity problem as a significant and increasing proportion of households became unable to afford the average nutritionally adequate food basket because of a combination of escalating food prices and falling wage incomes (Altman et al., 2009). The agricultural market reforms in South Africa have created a deeply competitive market structure exposing small-scale producers to the harsh globalized agro-food systems and networks (Traub and Jayne, 2008). The 1991 deregulation of maize meal prices and the 1996/97 dissolution of the Maize Board too bore adversarial impacts on the poor rural consumers because "several times since 2000, maize meal prices have reached very high levels" (Traub and Jayne, 2008, p.225). These deleterious effects notwithstanding, the deregulated and liberalized agricultural markets meant that South African farmers became able to hedge grain prices through the South African Futures Exchange and/or "presell a portion of their produce to food processors and wholesalers" (Makhura, 2013, p.94), at the same time when the majority of the rural households that experienced a transition from transitory to chronic food insecurity struggled to be hunger-free.

This article contents that the agricultural reforms imposed chronic adversarial underpinnings to rural household food insecurity because they failed to create downward pressure on maize meal prices whilst simultaneously allowing only two food-retailing companies, Shoprite Checkers and Pick ' $n$ Pay, to control about $80 \%$ of retail food sales (Traub and Jayne, 2008). Traub and Meyer (2007) establish that consumption of maize meal, a stable food for the majority of the rural poor, has been declining; and, this trend could be indicative of the increasing inaccessibility of this grain product due to the globalized governance of its production, marketing and pricing. The Minister of Finance has, in the February 2013 Budget Vote, increased the levy on fuel by 23c per litre from April 03, 2013 (Gordhan, 2013); and, the implementation took place on the heels of February and March 2013 fuel price soaring by $41 \mathrm{C}$ and 80c per litre, respectively (Engen, 2013). On July 03, 2013 the fuel price increased by 84c per litre (SAPA, 2013). These escalating prices on petrol will unavoidably precipitate soaring food prices; and, rural food insecurity transition from transitory to chronic will persist.

The phenomenon of supermarket food chain expansionism into small remote rural towns in South Africa's former 
Bantustans was the largest expansion in all of Africa (D'Haese and van Huylenbroeck, 2005; Jacobs, 2008, 2009a; Baiphethi and Jacobs, 2009). Supermarket food chains have since the late 1990s dominated the local rural markets in South Africa; and, the proportion of rural households who purchased foods from these networks than from informal traders and smallholders, was on the rise especially from 1994 (D'Haese and Van Huylenbroeck, 2005; Louw et al., 2007; Jacobs, 2008, 2009a; Baiphethi and Jacobs, 2009). Analyzing Statistics South Africa's (2007) 2005/06 Income and Expenditure Survey, it was found that $92 \%, 94 \%, 94 \%$ and $72 \%$ of black rural households purchased most of their grain products, meat, dairy products and vegetables from the supermarket chains and other formal retailers (Jacobs, 2008, 2009a; Baiphethi and Jacobs, 2009). Under these conditions, informal traders and smallholders struggled for survival. Supermarket chains used their economies of scale as well as centralized procurement, good retail logistics, better inventory management and consolidated distribution system to increase their competitive edge by undercutting food prices, as the first step before they rendered food inaccessible to most poor rural households through import parity pricing (D'Haese and van Huylenbroeck, 2005; Louw et al., 2007; Jacobs, 2008, 2009a; Baiphethi and Jacobs, 2009). Additionally, a series of measures such as requirements for particular production standards, organic farming certificates, food quality and safety regulations and packaging criteria are invoked to exclude smallholders from the agro-food chain market (Baiphethi and Jacobs, 2009). Informal traders too came to source a larger proportion of their fruit supplies in relatively large volumes from commercial producers than from smallholder farmers (Baiphethi and Jacobs, 2009). That is, informal traders themselves collude in a process that forces them to sell at large discounts, lest they lose their stockpiles because of their perishability (D'Haese and van Huylenbroeck, 2005; Louw et al., 2007). Given that supermarket food chains do not prefer once-off transactions that are common practice among the scattered smallholders, because they increase transaction costs and lower efficiency (D'Haese and van Huylenbroeck, 2005; Louw et al., 2007; Jacobs, 2008, 2009a; Baiphethi and Jacobs, 2009), rural smallholders in former Bantustans lost their traditional market irrecoverably.

Only four main supermarket chains (Shoprite, Pick 'n Pay, Spar and Woolworths), out of a total of 1700 in South Africa, dominated the sector since 2005, controlling about 90\% thereof (D'Haese and Von Huylenbroeck, 2005). The traditional retail community in rural villages, which consists of vendors, small shops and spazas, increasingly came under attack as the supermarket chains expanded. In contrast to small retail village shops, supermarkets offered greater selection of food at relatively lower prices, theoretically presenting "an important step towards livelihood development and food security" within rural localities (D'Haese and van Huylenbroeck, 2005, p.97). In practice, entry of supermarket chains intensified the exposure of poor rural households to hunger and malnutrition, especially those that relied on smallholder producers that are driven out of business. The bulk of foods sold in the small rural towns supermarkets in present-day South Africa are imported into these localities. Together with the expansion of supermarket food chains into remote rural areas in South Africa, the proliferation of cash demand together with the reduced capacity to practice subsistence agricultural activities for self-provisioning has meant that poor rural households are increasingly exposed to hunger and malnutrition (Aliber, 2009). That is, the primary effect of the hegemonic neoliberal agro-food systems has been to exacerbate household food security "stressors". The supermarket phenomenon has also curtailed the growth potential of local smallholder producers and informal traders, whose agricultural engagement was the mainstay for household survival in former Bantustans over many years.

\section{Global Food Price Determinant of Food Insecurity for Rural South Africa}

With the fashionable food market deregulation and liberalization, food access has come to be "embedded in markets, prices and legal systems" (Dorward et al., 2005; Webb and Thorne-Lyman, 2006). Expansion of South Africa's agro-food supermarket value chains into rurality is a typical example of how hegemonic neoliberalism came to decisively determine a spatially variable and unsustainable food security status. On the basis of the 2000=100 index, the average producer and consumer prices of horticultural and food products, respectively, increased by about 140 and 100 percentage points between 1990 and 2007 (author calculations from DoA, 2008 statistics). The consistent increase in the percentage annual change in producer prices of domestically produced goods is reflective of the increased adoption of the transfer and import parity pricing by South African producers. The sharp increase of the average prices of all vegetables sold on the fresh produce market in South Africa from R1 310/ton in 2000 to R2 500/ton in 2007 (DoA, 2008) cannot be conclusively explained through domestic variables alone.

Unsurprisingly, food prices have been responsible for driving inflation (Tolsi, 2011) for staples such as maize since at least 2006. Being a "wage good", "maize is so integral a part of the food-price sensitivity chain in South Africa that any price hike knocks onto other essential commodities' (Nevin, 2002, p.53). Nevin (2002) affirms that the global economy requires maize to produce beef, milk, cheese, chicken and eggs, just to name a few; and, Van Niekerk describes food and oil prices as the main stubborn culprits behind the production inflation pressures (Business Day, 29 August 2002). 
The escalation of the maize producer prices for South Africa by about 165 percentage points between 2000 and 2007, based on the 2000=100 index (author calculations from DoA, 2008 statistics), cannot be understood outside the global commodity pricing dynamics and the introduction of the new global price drivers such as biofuels. In the absence of a convincing alternative interpretation, Patel's conclusion that "the international food trading system" is the "real culprit" remains plausible (cited in Tolsi, 2011, p.7).

Presently, households' key escape valve for hunger and malnutrition is, decisively, "gaining wage or salary income" (Aliber, 2009). Further, Aliber (2009) finds that rural households spend a larger share of their food budgets on grain products and significantly lower proportions on meat and animal products. This finding cannot be interpreted to mean that poor rural households are producing meat and animal products for self-provisioning, because statistics show that South Africa has over the foreseeable past imported meat to supplement its food security needs (DoA, 2008). Simultaneously as the number of commercial farmers dropped, South Africa remained a net importer of wheat and meat (Makhura, 2013). Despite the substantial increase in the area allocated for grazing and meat production, development of the feedlot industry and "the phenomenal growth in broiler production, South Africa still remains a net importer of meat" (Makhura, 2013, p.90). It could as well be that rural households' need for meat and animal products is substituted for by indigenous vegetables because of the excessive costs of these energy-intensive products, given the effects of the import parity pricing, importation of meat and the soaring prices.

There have been deficits in the production and consumption of energy-intense meat (DoA, 2008). Based on the 2005 National Food Consumption Survey (NFCS), Labadarios et al. (2008) estimate that 52\% and 33\% of South African households, respectively, experienced hunger and risk of hunger. It is extrapolated from the NFCS that about $80 \%$ of households could not afford a basic nutritional basket of food at an average cost of R262 per person per month at the 2005 prices (Labadarios et al., 2008; Altman et al., 2009). Higher rural food prices, sustained through supermarket food chain expansionism, forced poor households to reduce consumption of meat to make it possible to buy staples (Altman et al., 2009). As rural households are increasingly unable to produce food for self-provisioning, they cannot generate replacement income that would have been available for purchasing energy-intensive foods. Former Bantustans consist of over 4 million smallholder farmers who have rarely produced surplus food (Jacobs, 2008, 2009a, 2009b). Households in the overcrowded lands, within former Bantustans, have "remained net importers of food" (Makhura, 2013, p.90). Democratization has not brought relief to the former Bantustans, notwithstanding the litany of support programmes for subsistence and small-scale emerging farmers. Whereas maize is a staple food for the majority of the rural indigenous population in the former Bantustans, the smallholder maize production yields have remained perpetually significantly lower than the productivity potential of the land (Walker and Schulze, 2006).

There is evidence of persistent annual deficits in the staple food maize and the energy-intense meat between 1990 and 2007 (see DoA, 2008). Logically, the importation of food can be expected to fuel domestic price hikes due to import parity pricing, thereby remaining inaccessible to the majority of income-starved rural households due to the distribution and structural inequities of the domestic food economy (Hendriks and Maunder, 2006; Seekings and Nattrass, 2006; Labadarios et al., 2008; Chopra et al., 2009). The year-on-year food price increase rate of $16.7 \%$ in 2008 from a mere $6.7 \%$ of 2006 (National Agricultural Marketing Council (NAMC), 2009) cannot be explained in terms of domestic food production and consumption dynamics alone. Despite the drop of this year-on-year food price increase rate to $8.4 \%$ in 2009 (NAMC, 2009), food has been rendered inaccessible to the poor rural households largely because of price escalations that have come with fluctuations in global commodity prices. Von Braun (2007), Evans (2009) and Hart (2009) agree that it is highly unlikely that low food prices would ever return because of the irreversible changes in the global agro-food system, the introduction of the new drivers of food demand such as biofuels, supply and pricing. The upward trend in prices is evident in almost all of South Africa's important foods, including grain products and vegetables.

It is clear that global food prices surged, especially since 2006, peaking in 2008; and, the result was that households that may have been vulnerable to transitory food insecurity would have been ultimately pushed into chronic food insecurity (Maunder and Wiggins, 2007; Drimie and Casale, 2009). Du Toit (2005) and Devereux (2009) argue that the prevailing structural conditions, rather than the shocks that trigger experiences of food insecurity, are actually responsible for the persistence of hunger, malnutrition, famine and food crisis that have pervaded sub-Saharan Africa in the previous century. According to Hart $(2009$, p.364), the determination of the effectiveness of household's coping mechanisms goes beyond the local scale to embrace its "location within the complex configurations of society as a whole", which involves global agro-food governance systems and networks. South Africa's agricultural sector has remained dualistic even in 2007 with about 39982 commercial farm units which are "vibrant, well integrated and highly capitalized"; and, about 4 million fluctuating subsistence and smallholder producers (Aliber and Hart, 2009; Makhura, 2013). The "unequal food economy" has remained evident and in 2007 the commercial sector, which occupied about $87 \%$ of the total agricultural land (see DoA, 2008), provided about 95\% of the agricultural output (Aliber and Hart, 2009). The 
cumulative impact of the "off-farm" governance and industrialization of agro-food system was to compound the crisis in the agri-food industry, both domestically and globally. For rural South Africa, the impact included undermining householdbased organization of agriculture and food production for self-provisioning.

\section{Conclusion}

This article has argued that the hegemonic neoliberalism's agro-food systems intervene in food security's temporal and intensity dimensions as well as internal and external vulnerability to (re)produce a paradoxical and unequal food economy for developing countries. The expansion of supermarket food chains into remote rurality, against the backdrop of upward price pressure exerted at the global scale flowing from import parity pricing and escalating commodity prices, as well as the erosion of the internal capabilities of the poor rural households to cope and deal with the food economy challenges, provides compelling evidence of the deleterious effects of the global agro-food systems on rural household food security. Hart (2009, p.365), sums up the effects of the global agro-food governance thus:

"South African consumers experience the effects of changes in the global food system as well as those taking place in the local food chain.... (because the) processes of modernization and change (have strengthened) the linkages between households and complex commodity chains and economic networks.... Even the most remote rural households feel the impacts of certain global events and changes (political, economic, social and environmental)".

The escalation of food prices in South Africa confirms the validity of this interconnectedness of the hegemonic and sub-hegemonic agro-food systems, the new drivers of global food prices, as well as their impacts on local rural food (in)security. In this context, rural food insecurity within former Bantustans is perpetuated by stressors associated with the hegemonic global neoliberal agro-food governance and the sub-hegemonic domestic supermarket food chains. The latter are among the leading agents of global agro-food governance through which rural food self-provisioning in South Africa continues to be subjugated and extraverted.

\section{References}

Aliber, M., 2009. Exploring Statistics South Africa's National Household Surveys as sources of information about household-level food security. Agrekon, 48(4), 384-409.

Aliber, M. and Hart, T.G.B., 2009. Should subsistence agriculture be supported as a strategy to address rural food insecurity? Agrekon, $48(4), 434-458$.

Altman, M., Hart, T.G.B. and Jacobs, P., 2009. Household food security status in South Africa. Agrekon, 48(4), 345-361.

Anderson, B. 2006. Transcending without transcendence: utopianism and an ethos of hope. Antipode, 38, 691-710.

Baiphethi, M.N. and Jacobs, P.T., 2009. The contribution of subsistence farming to food security in South Africa. Agrekon, 48(4), 458482.

Bridge, G. 2010. Geographies of peak oil: the other carbon problem. Geoforum, 41, 523-530.

Burch, D. and Lawrence, G. 2009. Towards a third food regime: behind the transformation. Agricultural Human Values, 26, 267-279.

Busch, L. and Bain, C. 2004. New! Improved? The transformation of the global agri-food system. Rural Sociology, 69(3), 321-346.

Buyx, A. and Tait, J. 2011. Ethical framework for biofuels. Science, 332, 540-541.

Campbell, H. and Le Heron, R. 2007. Supermarkets, producers and audit technologies: the constitutive micro-politics of food, legitimacy and governance. In Lawrence, G. and Burch, D. (eds.) Supermarkets and Agri-food Supply Chains: Transformations in the Production and Consumption of Foods. Edward Elgars, London, pp.131-153.

Chopra, M., Whitten, C. and Drimie, S. (2009). Combating malnutrition in South Africa. Global Alliance for Improved Nutrition, Working paper no. 1, www.gainhealth.org/documents Accessed: July 07, 2013.

Del Ninno, C., Dorosh, P.A. and Subbarao, K., 2007. Food aid, domestic policy and food security: contrasting experiences from South Asia and sub-Saharan Africa. Food Policy, 32, 413-435.

Department of Agriculture (DoA), 2008. Abstract: Agricultural Statistics. Government Printers, Pretoria.

Devereux, S. 2006. Identification of Methods and Tools for Emergency Assessments to Distinguish between Chronic and Transitory Food Insecurity, and to Evaluate the Effects of the Various Types and Combinations of Shocks on these Different Livelihood Groups. World Food Programme, Rome.

Devereux, S. 2009. Why does famine persist in Africa? Food Security, 1, 25-35.

D'Haese, M. and van Huylenbroeck, G., 2005. The rise of supermarkets and changing expenditure patterns of poor rural households case study in the Transkei area, South Africa. Food Policy, 30, 97-113.

Drimie, S. and Casale, M. 2009. Multiple stressors in Southern Africa: the link between HIVIAIDS, food insecurity, poverty and children's vulnerability now and in the future. Aids Care, 21(S1), 28-33.

Dorward, A., Kydd, J., Morrison, J. and Poulton, C. 2005. Institutions, markets and economic co-ordination: linking development policy to theory and praxis. Development and Change, 36(1), 1-25.

DuPluis, E.M. and Goodman, D. 2005. Should we go 'home' to eat? Towards a reflexive politics of localism. Journal of Rural Studies, 
21(3), 359-371.

Du Toit, A. 2005. Chronic and structural poverty in South Africa: challenges for action and research. Chronic Poverty Research Centre working paper no. 56, Programme for Land and Agrarian Studies, University of the Western Cape.

Engen 2013. Fuel Price. http://www.engen.co.za/home/apps/content/products_services/fuel_price/default.aspx Accessed: March 31 , 2013.

Essex, J. 2011. Idle hands are the devil's tools: the geopolitics and geoeconomics of hunger. Annals of the Association of American Geographers, 102, 191-207.

Evans, A. 2009. The Feeding of the Nine Billion: Global Food Security for the 21st Century. Royal Institute of International Affairs, London.

Fonte, M. 2006. Slow food's Presidia: what do small producers do with big retailers? In: Marsden, T.K. and Murdoch, J. (eds.) Between the Local and the Global: Confronting Complexity in the Contemporary Agri-food Sector. Elsevier, Oxford.

Friedberg, S. 2004. The ethical complex of corporate food power. Environment and Planning D: Society and Space, 22, 513-531.

Friedmann, H. 2005. From colonialism to green capitalism: social movements and emergence of food regimes. In: Buttel, F. and McMichael, P. (eds.) New Directions in the Sociology of Global Development. Elsevier, Oxford, pp.227-264.

Fulponi, L. 2006. Private voluntary standards in the food system: the perspective of major food retailers in OECD countries. Food Policy, 31(1), 1-13.

Gebbers, R. and Adamchuck, V. 2010. Precision agriculture and food security. Science, 327, 828-831.

Ghosh, J. 2010. The unnatural coupling: food and global finance. Journal of Agrarian Change, 10(1), 72-86.

Glemarec, Y. and Puppim de Oliveira, J.A. 2012. The role of the visible hand of public institutions in creating a sustainable future. Public Administration and Development, 32, 200-214.

Godfrey, H.C.J., Crute, I.R., Haddad, L., Lawrence, D., Muir, J.F., Nisbett, N., Pretty, J., Robinson, S., Toulmin, C. and Whiteley, R. 2010. The future of the global food system. Philosophical Transactions of the Royal Society B: Biological Sciences, 365, 27692777.

Gordhan, P. 2013. Budget Speech 2013. http://www.pastelpayroll.co.za/Pastel-Payroll-Software-Training/Pastel-Payroll-SoftwareSeminars.asp Accessed: March 31, 2013.

Halfacree, K. 2007. Trial by space for a 'radical rural': introducing alternative localities, representations and lives. Journal of Rural Studies, 23, 125-141.

Hart, T.G.B., 2009. Exploring definitions of food insecurity and vulnerability: time to refocus assessments. Agrekon, 48(4), 362-383.

Hendricks, S.L. and Maunder, E.M.W. 2006. Reflecting on the FIVIMS.ZA pilot and food insecurity and vulnerability: Modeling approaches to advise on future directions. Paper prepared for the World Food Programme. African Centre for Food Security, Pietermaritzburg.

Holt-Gimenez, E. and Shattuck, A. 2011. Food crisis, food regimes and food movements: rumblings of reform or tides of transformation? Journal of Peasant Studies, 38(1), 109-144.

Horlings, L.G. and Marsden, T. 2011. Towards the real green revolution? Exploring the conceptual dimensions of a new ecological modernization of agriculture that could 'feed the world'. Global Environmental Change, 21, 441-452.

Institute for Poverty Land and Agrarian Studies (PLAAS), 2009. Strategies to support South African smallholders as a contribution to government's second economy strategy. Draft report commissioned by the Second Economy Strategy Project. PLAAS, University of the Western Cape, Cape Town.

Jacobs, P. 2008. Market development and smallholder farmers: a selective literature survey. Background paper for the Second Economy Project. October 2008, HSRC, Pretoria.

Jacobs, P. 2009a. Agricultural Market Reforms and the Rural Poor in South Africa. Research Paper of the 2009 PLAAS Poverty Workshop, University of the Western Cape.

Jacobs, P. 2009b. The status of household food security targets in South Africa. Agrekon, 48(4), 410-433.

Labadarios, D., Swart, R., Maunder, E.M.W., Kruger, H.S., Gericke, G.J., Kuzwayo, P.M.N., Ntsie, P.R., Steyn, N.P., Schloss, I., Dhansay ,M.A., Jooste, P.L., Dannhauser, A., Nel, J.H., Molefe, D. and Kotze, T.J.vW. 2008. National Food Consumption Survey-Fortification Baseline (NFCS-FB-I) South Africa, 2005. South African Journal Clinical Nutrition 21(3), 245-300.

Lang, T. 2010. Crisis? What crisis? The normality of the current food crisis. Journal of Agrarian Change, 10(1), 87-97.

Lang, T. and Heasman, M. 2004. Food Wars: the Global battle for Mouths, Minds and Markets. Earthscan, London.

Louw, A., Vermeulen, H., Kirsten, J. and Madevu, H. 2007. Securing small farmer participation in supermarket supply chains in South Africa. Development Southern Africa, 24(4), 539-551.

Makhura, M. (ed.) 2013. History of the Land Bank: Financing Agriculture for 100 Years. the Land Bank Public Information Centre, Pretoria.

Maloni, M. and Brown, M. 2006. Corporate social responsibility in the supply chain: an application in the food industry. Journal of Business Ethics, 68(1), 35-52.

Marsden, T. 2011. From post-productionism to reflexive governance: contested transitions in securing more sustainable food futures. Journal of Rural Studies, doi:10.1016/j.jrurstud. 2011.10.001.

Maunder, N. and Wiggins, S. 2007. Food security in Southern Africa: changing the trend? Review of lessons learnt on recent responses to chronic and transitory hunger. Natural Resource Perspective, 106, 1-4.

McMichael, P. 2004. A food regime analysis of the 'world food crisis'. Agriculture and Human Values, 62, 281-295.

Moore, J.W. 2010. The end of the road? Agricultural revolutions in the capitalist world-ecology, 1450-2010. Journal of Agrarian Change, 
10, 389-413.

Murphy, S. 2010. Biofuels: finding a sustainable balance for food and energy. In: Lawrence, G., Lyons, K. and Wallington, T. (eds.) Food Security, Nutrition and Sustainability. Earthscan, London, pp. 223-237.

National Agricultural Marketing Council (NAMC), 2009. The South African Food Cost Review, 2008. NAMC, Pretoria.

Nevin, T. 2002. The unbearable pressure of being President Mbeki. African Business, 281, 52-54.

Oldewage-Theron, W.H., Dicks, E.G. and Napier, C.E. 2006. Poverty, household food insecurity and nutrition: coping strategies in an informal settlement in the Vaal Triangle, South Africa. Public Health, 120, 795-804.

Parfitt, J., Barthel, M. and MacNaughton, S. 2010. Food waste within food supply chains: quantification and potential for change to 2050. Philosophical Transactions of the Royal Society B: Biological Sciences, 365, 3065-3081.

Peet, R. 2002. Ideology, discourse, and the geography of hegemony: from socialist to neoliberal development in post-apartheid South Africa. Antipode, 34(1), 54-84.

Renard, M-C. 2003. Fair trade: quality, market and conventions. Journal of Rural Studies, 19, 87-96.

Rosin, C. 2012. Food security and the justification of productionism in New Zealand. Journal of Rural Studies, doi:10.1016/j.jrurstud.2012.01.015.

Sage, C. 2012. The interconnected challenges for food security from a food regimes perspective: energy, climate and malconsumption. Journal of Rural Studies, doi:10.1016/j.jurstud.2012.02.005.

Schurman, R. and Munro, W. 2010. Fighting for the Future of Food: Activists versus Agribusiness in the Struggle over Biotechnology. University of Minnesota Press, Minneapolis.

Seekings, J. and Nattrass, N. 2006. Class, Race and Inequality in South Africa. University of KwaZulu-Natal Press, Pietermaritzburg.

South African Press Association (SAPA), 2013. South Africa: Petrol to Rise by 84 Cents a Litre. http://www.sapa.co.za/ Accessed: June 29, 2013.

Stock, P. and Carolan, M. 2012. A utopian perspective on global food security. In: Rosin, C., Stock, P. and Campbell, H. (eds.) Food Systems Failure: the Global Food Crisis and the Future of Agriculture. Earthscan, London, pp. 114-127.

Tolsi, N. 2011. Alarm raised over decline in maize crop. Mail \& Guardian, June 03-09, 2011, Johannesburg, p.7.

Traub, L.N. and Jayne, T.S. 2008. The effects of price deregulation on maize marketing margins in South Africa. Food Policy, 33, 224236.

Traub, L.N. and Meyer, F. 2007. Alternative Staple Food Trade and Market Policy Interventions: Country Level Assessment of South Africa. Paper Presented for FAO Workshop on Staple Food Trade and Market Policy Options for Promoting Development in Eastern and Southern Africa, FAO.

Van der Horst, D. and Vermeylen, S. 2011. Spatial scale and social impacts of biofuel production. Biomass Bioenergy, 35, $2435-2443$.

Van der Ploeg, J.D. 2008. The New Peasantries: Struggles for Autonomy and Sustainability in an Era of empire and Globalization. Earthscan, London.

Van der Ploeg, J.D. 2010. The food crisis, industrialized farming and the imperial regime. Journal of Agrarian Change, 10(1), 98-106.

Von Braun, J. 2007. The World Food Situation: New Driving Forces and Required Actions.

International Food Policy Research Institute, Washington.

Walker, N.J. and Schulze, R.E. 2006. An assessment of sustainable maize production under different management and climate scenarios for smallholder agro-ecosystems in KwaZulu-Natal, South Africa. Physics and Chemistry of the Earth, 31, 995-1002.

Webb, P., Coates, J., Frongillo, E.A., Rogers, B., Swindale, A. and Bilinsky, P. 2006. Measuring household food insecurity: Why it's so important and yet so difficult to do. The Journal of Nutrition, 136(5), 1404S-1408S.

Webb, P. and Thorne-Lyman, A. 2006. Entitlement failure from a food quality perspective: the life and death role of vitamins and minerals in humanitarian crises. WIDER Research Paper 2006/140, United Nations University - World Institute for Development Economics Research (UNU-WIDER), Helsinki, Finland.

Weiss, T. 2007. The Global Food Economy: the Battle for the Future of Farming. Zed Books, London.

Whatmore, S. 1995. From farming to agribusiness: the global agro-food system. In Johnston, R.J. Taylor, P.J. and Watts, M.J. (eds.) Geographies of Global Change: Remapping the World in the Late Twentieth Century. Blackwell, Oxford, pp. 36-49.

World Bank 2007. World Development Report 2008 Overview: Agriculture for development. International Bank for Reconstruction and Development/World Bank, Washington DC. 